\title{
HIDROLISIS LIGNOSELULOSA PELEPAH DAN TANDAN KOSONG KELAPA SAWIT DENGAN KATALIS ZIRKONIA TERSULFATASI
}

\section{LIGNOCELLULOSIC HYDROLYSIS OF FROND AND EMPTY FRUIT BUNCHES USING SULFATED ZIRCONIA CATALYST}

\section{Anis Kristiani ${ }^{*}$, Kiky Corneliasari Sembiring, Haznan Abimanyu, dan Fauzan Aulia}

\author{
Pusat Penelitian Kimia - Lembaga Ilmu Pengetahuan Indonesia (LIPI) \\ Kawasan PUSPIPTEK Serpong, Tangerang Selatan 15314 \\ E-mail: anis.kristiani87@gmail.com
}

Diterima: 19 Agustus 2013, Direvisi: 8 Agustus 2013, Disetujui: 6 September 2013

\section{ABSTRAK}

Biomasa lignoselulosa yang berupa pelepah dan Tandan Kosong Kelapa Sawit (TKKS) merupakan bahan baku generasi kedua yang potensial sebagai bahan alternatif pengganti bahan baku fosil untuk produksi etanol. Penggunaan lignoselulosa diharapkan mampu menciptakan proses yang lebih ramah lingkungan. Pemanfaatan bahan-bahan lignoselulosa untuk diubah menjadi etanol melalui empat proses utama, yakni pretreatment, hidrolisis/sakarifikasi, fermentasi, serta pemisahan dan pemurnian produk etanol. Penelitian ini ditujukan untuk melakukan optimasi proses hidrolisis TKKS dan pelepah dengan bantuan zirkonia tersulfatasi yang telah dikarakterisasi sifat fisika dan kimianya sebagai katalis asam padat. Proses hidrolisa terkatalisis zirkonia tersulfatasi pada suhu $160{ }^{\circ} \mathrm{C}$ memberikan hasil gula pereduksi (TRS/Total Reducing Sugar) tertinggi, yakni sebesar 17,51 \% dengan waktu hidrolisis 3 jam untuk bahan baku TKKS, sedangkan untuk bahan baku pelepah memberikan hasil gula pereduksi tertinggi, yakni sebesar 19,23\% dengan waktu hidrolisa 2 jam.

Kata kunci : Hidrolisa, katalis asam padat, lignoselulosa, pelepah, TKKS, zirkonia tersulfatasi

\section{ABSTRACT}

Lignocellulosic biomass which are frond and empty fruit bunches (EFB) is second generation raw material for ethanol production. Lignocellulose usage is expected to create a green process. Utilization of lignocellulose materials into ethanol involved four main processes, i.e pretreatment, hydrolysis/sacharification, fermentation, distillation and dehydration ethanol that was product. This research aims to optimize hydrolysis process of EFB and frond by using sulfated zirconia catalyst characterized its physical and chemical properties as a solid acid catalyst. Catalytic hydrolysis process conducted at $160{ }^{\circ} \mathrm{C}$ for 3 hours gave the highest TRS (Total Reducing Sugar) which is $17,51 \%$ for EFB while for frond for 2 hours which is 19,23\% .

Keyword: Hydrolysis, solid acid catalyst, lignocellulose, frond, EFB, sulfated zirconia.

\section{PENDAHULUAN}

Biomasa lignoselulosa yang tersusun dari selulosa, lignin, hemiselulosa, dan ekstraktif merupakan sumber terbarukan yang keberadaannya melimpah dan bersifat ramah lingkungan. Seiring dengan meningkatnya pemahaman mengenai pemanasan global dan keterbatasan bahan bakar fosil, berbagai usaha untuk menggunakan lignoselulosa 
sebagai bahan alternatif untuk bahan bakar dan bahan kimia terus dilakukan ${ }^{(1,2)}$. Hidrolisa selulosa menjadi gula terfermentasi merupakan tahapan penting di berbagai proses produksi biofuel dari selulosa melalui jalur biologi. Hidrolisa merupakan suatu proses kimia untuk mengkonversi polisakarida menjadi monosakarida. Proses hidrolisa lignoselulosa meliputi hidrolisa secara enzimatis (menggunakan enzim selulase) dan hidrolisa secara asam (menggunakan asam encer pada temperatur tinggi dan asam kuat pada temperatur dan tekanan rendah) $)^{(3)}$. Selanjutnya, beberapa proses kimia juga mulai dilakukan untuk mengubah monosakarida menjadi bahan bakar dan bahan kimia bernilai tambah ${ }^{(4,5)}$.

Berbagai teknologi proses, seperti pemisahan dan depolimerisasi maupun konversi secara katalitik dilakukan berkaitan dengan lignoselulosa ini. Secara umum, sulit untuk melarutkan lignoselulosa dalam bentuk aslinya karena jaringan lignin yang terhubung secara tiga dimensi dan ikatan hidrogen yang kuat di antara matriks polimerik. Tidak dapat diaksesnya lignoselulosa oleh media pelarut tersebut sangat menghambat efisiensi pemanfaatan biomasa lignoselulosa ${ }^{(6)}$. Penggunaan teknologi berbasis ionic liquid telah membuka metode pengolahan lignoselulosa yang ramah lingkungan. Rogers $\mathrm{dkk}^{(7)}$ melaporkan bahwa ionic liquid berbasis imidazolium dapat melarutkan selulosa hingga $20 \%$ dan selulosa amorf dapat dipisahkan dari lignoselulosa dengan menambahan anti solven, seperti air dan etanol, pada larutan ionic liquid. Sejak saat itu, ionic liquid telah disintesis untuk mengembangkan sistem solven yang lebih efisien dan ramah lingkungan untuk melarukan selulosa ${ }^{(8-11)}$ dan lignoselulosa ${ }^{(9)}$.

Penggunaan katalis asam sangat berkembang pesat di dalam industri kimia. Teknologi yang melibatkan cairan asam yang bersifat sangat korosif, berbahaya dan berpolusi telah digantikan dengan padatan asam, seperti lempung yang diasamkan, zeolit, resin penukar ion dan oksida logam.
Tidak hanya kekuatan asam namun juga tipe keasaman (Bronsted dan Lewis) yang mempengaruhi aktivitas dan selektivitas. Zirkonia tersulfatasi telah digunakan dalam berbagai aplikasi dan memegang peranan penting dalam reaksi di sejumlah industri. Permukaan zirkonia oksida diketahui memiliki aktivitas katalitik. Zirkonia oksida atau zirkonia yang dimodifikasi dengan anion, seperti ion sulfat, membentuk katalis super asam yang menunjukan aktivitas katalitik yang luar biasa untuk mengkatalisis berbagai reaksi ${ }^{(12)}$.

Katalis Zeolit- $\mathrm{H}$ dan katalis tersulfatasi serta tersulfonasi seperti zirkonia tersulfatasi, diharapkan memiliki aktivitas katalitik pada hidrolisa selulosa ${ }^{(13)}$. Zirkonia bersifat nonkorosi, aktif dan stabil secara katalitik di berbagai kondisi. Katalis dapat disintesis dengan beberapa metode, tetapi metode solgel yang paling sering digunakan saat ini. Zirkonia yang diperoleh dengan metode ini memiliki sifat yang sangat diharapkan berkaitan dengan partikelnya yang berukuran nano dan porositasnya yang baik. Sifat katalis berbasis zirkonia yang diperoleh dengan metode sintesis sol-gel tergantung pada sejumlah parameter, yakni prekursor senyawa, suhu dan $\mathrm{pH}$, konsentrasi larutan, aging padatan, jenis pelarut, dan promotor yang digunakan ${ }^{(14)}$.

Tujuan dari penelitian ini adalah untuk melakukan optimasi proses hidrolisa lignoselulosa dengan bantuan zirkonia tersulfatasi sebagai katalis asam padat. Optimasi proses hidrolisa lignoselulosa dilakukan dengan melakukan variasi waktu hidrolisa.

\section{BAHAN DAN METODA}

\section{Bahan}

Bahan baku yang digunakan dalam penelitian ini adalah TKKS dan pelepah yang belum dan sudah mengalami proses pretreatment dengan menggunakan $\mathrm{NaOH}$ $10 \%$; ionic liquid 1-n-butyl-3methylimidazolium chloride (BMIMCl) sebagai pelarut, dan akuades. Sedangkan 
katalis yang digunakan adalah zirkonia tersulfatasi hasil preparasi dengan metode sol gel termodifikasi surfaktan. Prekursor zirkonia yang digunakan dalam preparasi katalis adalah zirconia (IV) butoxide. Katalis zirkonia tersulfatasi tersebut sudah dikarakterisasi sifat fisik dan kimianya, yakni kristalinitas dengan menggunakan XRD ( $X$ Ray Diffraction), luas permukaan spesifik dengan Sorptomatic 1800 Carlo Erba Instrument, keasaman dengan metode gravimetri dan keberadaan situs asam dengan FTIR (Fourier Transformed Infra Red) ${ }^{(15)}$.

\section{Metoda}

\section{Proses Hidrolisa}

Uji aktivitas hidrolisa dilakukan pada suhu $160{ }^{\circ} \mathrm{C}$ dengan komposisi bahan baku sebanyak 0,2 g; ionic liquid $\mathrm{BMIMCl}$ sebagai pelarut sebanyak $3,8 \mathrm{~g}$; air sebagai anti solven sebanyak $0,25 \mathrm{ml}$; dan katalis sebanyak 0,1 g. Variasi waktu hidrolisa dilakukan pada 2, 3, 4, dan 8 jam. Setelah reaksi, campuran selulosa, ionic liquid, dan katalis, dipisahkan dengan menambahkan air sebanyak $10 \mathrm{~mL}$. Larutan akhir ditampung dan dianalisa konsentrasi TRSnya dengan metode DNS. Reaksi hidrolisa dilakukan pada reaktor bertekanan seperti terlihat pada Gambar 1.

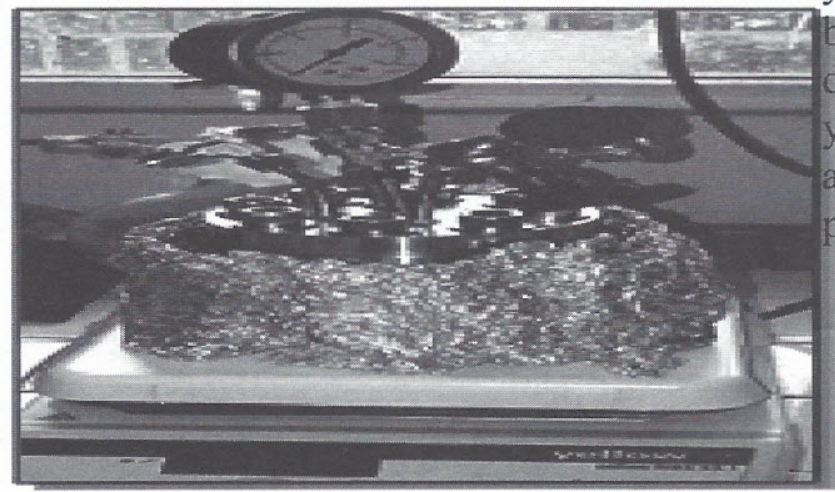

Gambar 1. Reaktor Hidrolisis

\section{Analisa Produk Cair}

Metode DNS (3,5-dinitrosalicylic acid) merupakan metode yang digunakan untuk menganalisa total gula pereduksi (TRS) dilakukan sebagai berikut: sebanyak $0,25 \mathrm{~mL}$ reagen DNS dan 0,25 $\mathrm{mL}$ dari sampel hasil reaksi dicampur dan dipanaskan di dalam penangas air pada suhu $95-100^{\circ} \mathrm{C}$ selama 5 menit, kemudian didinginkan sampai suhu kamar. Campuran tersebut kemudian diencerkan dengan $2 \mathrm{~mL}$ air. Intensitas warna dari campuran akhir tersebut kemudian diukur dengan menggunakan UV-Vis Spektrofotometer pada panjang gelombang $540 \mathrm{~nm}$. Konsentrasi TRS dihitung berdasarkan kurva standar yang diperoleh dari glukosa ${ }^{(16)}$.

\section{HASIL DAN PEMBAHASAN}

Komponen kimia terbesar TKKS dan pelepah terdiri dari selulosa, hemiselulosa dan lignin sehingga limbah kelapa sawit ini disebut lignoselulosa. Pretreatment dilakukan untuk menurunkan kandungan lignin dan hemiselulosa pada bahan baku. Hal tersebut dilakukan karena keberadaan lignin akan mengganggu aktivitas katalis. Untuk menentukan perbedaan TKKS dan pelepah yang sudah mengalami proses pretreatment, bahan baku sebelum dan setelah pretreatment lianalisa komponen kimia penyusunnya, akni lignin, selulosa dan hemiselulosa. Hasil nalisa komponen bahan baku ditunjukkan ada Tabel 1.

Tabel 1. Hasil Analisa Komponen Kimia Bahan Baku

\begin{tabular}{lccc}
\hline \multicolumn{1}{c}{ Bahan Baku } & $\begin{array}{c}\text { Lignin } \\
\mathbf{( \% )}\end{array}$ & $\begin{array}{c}\text { Selulosa } \\
\mathbf{( \% )}\end{array}$ & $\begin{array}{c}\text { Hemiselulosa } \\
\mathbf{( \% )}\end{array}$ \\
\hline TKKS & 36,40 & 30,85 & 13,94 \\
TKKS hasil pretreatment & 21,97 & 52,30 & 21,32 \\
Pelepah & 29,50 & 40,01 & 30,78 \\
Pelepah hasil pretreatment & 26,36 & 47,84 & 8,23 \\
\hline
\end{tabular}


Hasil analisa komponen menunjukkan bahwa pretreatment dengan $\mathrm{NaOH}$ mampu menghilangkan $14,5 \%$ lignin pada TKKS dan $3,1 \%$ lignin pada pelepah. Bahan baku tersebut kemudian digunakan untuk mengetahui pengaruh pretreatment pada proses hidrolisa oleh katalis zirkonia tersulfatasi dan hasil uji aktivitasnya ditunjukkan pada Tabel 2.

Tabel 2. Persentase Yield TRS Hidrolisa Lignoselulosa

\begin{tabular}{lc}
\hline \multicolumn{1}{c}{ Bahan Baku } & $\begin{array}{c}\text { Yield TRS } \\
(\mathbf{\%})\end{array}$ \\
\hline TKKS & 8,61 \\
TKKS hasil pretreatment & 17,51 \\
Pelepah & 9,37 \\
Pelepah hasil pretreatment & 16,57 \\
\hline (Bahan baku 0,2g, katalis $0,1 \mathrm{~g}$, Ionic Liquid \\
BMIMCl 3,8 g, hidrolisa $160^{\circ} \mathrm{C} ; 3$ jam)
\end{tabular}

Tabel 2 menunjukkan bahwa pretreatment dengan $\mathrm{NaOH}$ mengakibatkan kenaikan persentase yield TRS untuk bahan baku TKKS, yakni dari 8,61 \% menjadi $17,51 \%$ dan untuk pelepah, yakni 9,37\% menjadi 16,57 \%. Adanya peningkatan persentase yield TRS ini berkaitan dengan kandungan lignin yang mengalami penurunan dan kandungan selulosa yang mengalami kenaikan setelah proses pretreatment dengan $\mathrm{NaOH}$. Optimasi reaksi hidrolisa TKKS dan pelepah yang sudah mengalami proses pretreatment dengan $\mathrm{NaOH}$ dilakukan dengan melakukan variasi waktu hidrolisa seperti ditunjukkan pada Gambar 2.

Dari Gambar 2 tampak pada reaksi hidrolisa TKKS hasil pretreatment dengan $\mathrm{NaOH}$ bahwa kenaikan waktu hidrolisa dari 2 jam ke 3 jam berpengaruh pada peningkatan persentase yield TRS yaitu dari $13,88 \%$ menjadi $17,51 \%$. Kenaikan waktu hidrolisa menjadi 4 dan 8 jam menunjukkan penurunan persentase TRS yang terdeteksi pada produk cair hasil reaksi, yaitu menjadi $9,43 \%$ dan $9,37 \%$.

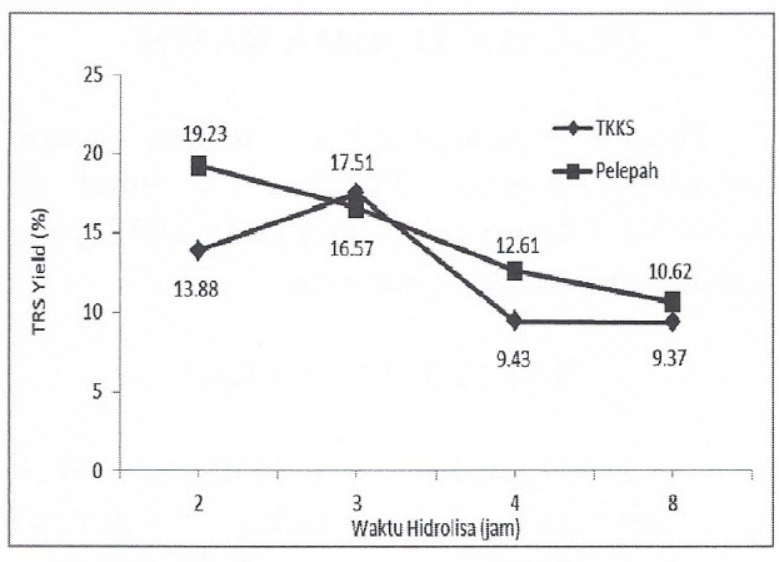

Gambar 2. Hidrolisa TKKS dan pelepah hasil pretreatment $\mathrm{NaOH}$ dengan variasi waktu hidrolisa dengan bahan baku $0,2 \mathrm{~g}$; katalis $0,1 \mathrm{~g}$; Ionic Liquid BMIMCl : 3,8g; suhu $160^{\circ} \mathrm{C}$

Sedangkan pada hidrolisa pelepah hasil pretreatment dengan $\mathrm{NaOH}$ menunjukkan bahwa persentase yield TRS tertinggi pada waktu hidrolisa 2 jam dan dengan perpanjangan waktu hidrolisa mengakibatkan penurunan persentase TRS yang terdeteksi setelah reaksi. Persentase yield TRS tertinggi pada hidrolisa pelepah yakni sebesar 19,23 \% dan lebih tinggi daripada persentase yield TRS tertinggi pada TKKS yang hanya sebesar $17,51 \%$. Penurunan persentase yield TRS yang terjadi dengan penambahan waktu reaksi kemungkinan dikarenakan dekomposisi lanjut gula pereduksi yang sudah terbentuk.

\section{KESIMPULAN}

Hidrolisa dengan katalis zirkonia tersulfatasi terhadap bahan baku TKKS dan pelepah menunjukkan bahwa bahan baku yang telah mengalami pretreatment dengan $\mathrm{NaOH}$ menghasilkan gula pereduksi lebih tinggi pada larutan hasil hidrolisa daripada bahan baku yang tidak mengalami treatment. Hidrolisa pelepah hasil pretreatment meberikan gula pereduksi lebih tinggi $(19,23$ $\%)$ daripada hidrolisa TKKS $(17,51 \%)$. 